\title{
Constructed wetlands as an alternative for arsenic removal
}

\author{
C.E. Corroto ${ }^{1}$, A. Iriel, E. Calderón ${ }^{2}$, A. Fernádez-Cirelli ${ }^{2} \&$ A.L. Pérez Carrera ${ }^{2}$ \\ ${ }^{1}$ Agua y Saneamientos Argentinos S.A. (AySA S.A.) and Centro de Estudios Transdisciplinarios del Agua, \\ Universidad de Buenos Aires and Buenos Aires, Argentina \\ ${ }^{2}$ Facultad de Ciencias Veterinarias, Centro de Estudios Transdisciplinarios del Agua (CETA - UBA), \\ Universidad de Buenos Aires, Buenos Aires, Argentina
}

\begin{abstract}
In Argentina, approximately $10 \%$ of the population consumes water with arsenic concentrations higher than the WHO and Argentine Food Code recommendations $\left(10 \mu \mathrm{g} \mathrm{L}^{-1}\right)$. Because of this, in some places reverse osmosis represented an immediate and effective solution to solve this problem. However, this process has a secondary effluent known as "concentrate" where all the elements present in the feed flow to this system are more concentrated. Sometimes, this residue is discharged in natural water bodies. In this work, the phytoremediation with constructed wetlands was proposed to solve the problem. The study was made from the design and construction of 3 prototypes, one of them implanted with J. effusus, another with C. haspan and a control one with substrate only. The percentages of arsenic removal were close to $50 \%$ with $C$. haspan and $80 \%$ with $J$. effusus. The technology was considered an efficient and environmentally sustainable solution to reverse osmosis effluent treatment and disposal.
\end{abstract}

\section{INTRODUCTION}

Arsenic (As) is a pollutant of groundwater, present in different regions of Argentina. Particularly in district of La Matanza, province of Buenos Aires, the reverse osmosis is used for As removal. The disadvantage of this technology is the secondary effluent (concentrate) that contains high levels of salts. The As concentration in the concentrate may be between 2 and 4 times higher than in the feed flow. This effluent is discharged in the river and may cause an important environmental problem due to the As concentration. For this reason, the objective of this study is to analyze the possibility of using constructed wetlands $(\mathrm{CW})$ as a sustainable, cost-effective, and environmentally friendly alternative for As removal. Wetlands are considered as a complex bioreactor due to the interaction between microbial communities, plants, soils and sediments (Kadlec \& Wallace, 2009). Vegetal species used in CW should be tolerant to heavy metals, capable to immobilize the pollutant in roots, cheap, environmentally sustainable, easy to implement and should not have translocation of heavy metals to shoots and stems (Ciarkowska et al., 2017; Yadav et al., 2012). The most important factors that should be considered in the implementation and operation are: As speciation, vegetation, substrate, microorganism, environmental conditions and physicochemical parameters $(\mathrm{pH}$, oxide-reduction potential and temperature) (Lizama et al., 2011; Valles Aragón et al., 2013).

\section{MATERIALS AND EXPERIMENTAL METHODOLOGY}

\subsection{Materials}

Working solutions were obtained from the secondary effluent of a reverse osmosis process plant in Buenos Aires province.

In each of the $\mathrm{CW}, 220 \mathrm{~kg}$ of a mixture of inert gravel (average diameter $=2 \mathrm{~mm}$ ) and $10 \%$ of laterite were used as substrate. The $\mathrm{pH}$, electrical conductivity and textural composition were determined. The vegetal species used in this work were: Cyperus haspan (C. haspan) and Juncus effusus (J. effusus).

\subsection{Experimental methodology}

The experiments were performed by using a continuous regime. Three prototypes were put in operation inside a greenhouse, two of them with different plants (A: Cyperus haspan; B: Juncus effusus) and one only with the substrate (C: Control). The initial concentration of As in the concentrate of reverse osmosis was, on average, $100 \mathrm{~g} \mathrm{~L}^{-1}$, the liquid level was $3 \mathrm{~cm}$ below the surface. The experiments were carried out for 419 days at room temperature. The monitored parameters were: flow, $\mathrm{pH}$, conductivity, oxidation reduction potential, humidity and temperature. During this time, several samples were taken in the inflow and outflow in all the wetlands. Samples were filtered $(0.45 \mu \mathrm{m})$ for solid removal and As concentrations were determined in 


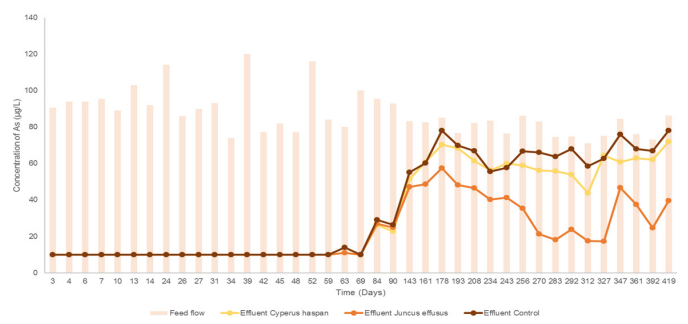

Figure 1. Profile of As concentration in the feed and out flow of each constructed wetlands during the period of operation.

the supernatant, the As analysis was carried out using ICP-MS (Agilent, model $7500 \mathrm{CX}$ with collision/ reaction cell).

\section{RESULTS AND DISCUSSION}

\subsection{Concentrate physicochemical properties}

The results of the analysis of the physicochemical parameters in the reverse osmosis concentrate were: $\mathrm{pH}=8.2$, conductivity $=1394 \mu \mathrm{S} \mathrm{cm}^{-1}, \mathrm{Cl}^{-}=$ $32.7 \mathrm{mg} \mathrm{L}^{-1}, \mathrm{SO}_{4}^{-2}=31.6 \mathrm{mg} \mathrm{L}^{-1}, \mathrm{NO}_{3}^{-}=76.3 \mathrm{mg} \mathrm{L}^{-1}$, $\mathrm{NO}_{2}^{-}=0.02 \mathrm{mg} \mathrm{L}^{-1}, \mathrm{~F}^{-}=2.0 \mathrm{mg} \mathrm{L}^{-1}$, alkalinity $=$ $653 \mathrm{mg} \mathrm{L}^{-1}, \mathrm{Na}^{+}=292 \mathrm{mg} \mathrm{L}^{-1}, \mathrm{~K}^{+}=14 \mathrm{mg} \mathrm{L}^{-1}, \mathrm{Fe}$ (total) $<0.05 \mathrm{mg} \mathrm{L}^{-1}, \mathrm{Mg}^{2+}=17 \mathrm{mg} \mathrm{L}^{-1}$, total hardness $\left(\mathrm{CO}_{3} \mathrm{Ca}\right)=140 \mathrm{mg} \mathrm{L}^{-1}, \mathrm{NH}_{4}^{+}<0.05 \mathrm{mg} \mathrm{L}^{-1}$, $\mathrm{PO}_{4}^{-3}=1.44 \mathrm{mg} \mathrm{L}^{-1}$.

\subsection{Substrate characterization}

The analysis of textural characteristic of the laterite and gravel were made with Bouyoucos method. The results showed that laterite has $55 \%$ clay, $17.50 \%$ silt and $27.50 \%$ sand and its class is clayey. The $\mathrm{pH}$ of the laterite was 5.56 and the electrical conductivity, $38 \mu \mathrm{S} \mathrm{cm}^{-1}$. The principal components were Al 37\%, Si $27 \%$ and $\mathrm{Fe} 33 \%$. On the other hand, the physicochemical characteristics of the gravel presented $\mathrm{pH}$ of 7.22, and electrical conductivity $21 \mu \mathrm{S} \mathrm{cm}^{-1}$. The textural class was $1.25 \%$ clay and $98.75 \%$ sand.

\subsection{Arsenic removal}

The Figure 1 shows the As concentration profile, as well as the inflow and outflow in CW systems during the 419 days of operation. In the stabilization period ( 90 days), As concentration in the outflow was $\leq 10 \mu \mathrm{g} \mathrm{L}^{-1}$. This effect was probably favored by laterite presence in the substrate. After this stage, in each of the $\mathrm{CW}$ the As concentration in outflow increases as a result of substrate saturation. In the case of the prototype planted with Juncus effusus (PB) the vegetal species were protagonists in the As removal. On the contrary, the trend of the curves of the prototype planted with Cyperus haspan (PA) and the prototype

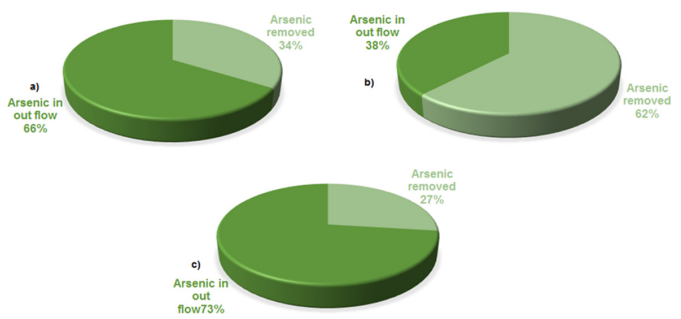

Figure 2. Percentage of As mass in the feed and out flow of constructed wetland during the operation period where these are, a) constructed wetland implanted with Cyperus haspan (PA), b) constructed wetland implanted with Juncus effuses (PB) and c) constructed wetland not implanted (Control or PC).

without plants (PC), in the last time, the values of the As concentration were similar in the feed and outflow.

However, in the curve for $\mathrm{PB}$ (Fig. 1) it is possible to see that the values of As concentration in output flow were lower than in the input, this indicates that there was removal of the contaminant.

During all the period of operation, the PB presented higher percentage of As removal and it was also possible to observe after performing an analysis of the percentage of mass in feed and out flow as shown in Figure 2. In this graph the As removal in PA was similar to PC, this shows the low efficiency of $C$. haspan to removal the pollutant in working conditions.

\section{CONCLUSIONS}

The maximum As removal was efficient, $\mathrm{CW}$ planted with $C$. haspan and J. effusus achieved removal values of $50 \%$ and $80 \%$ respectively, while the unplanted, only $35 \%$. It should be noted that during the stabilization period (90 days) the maximum As removal was higher due to the laterite presence. However, the $J$. effusus species was found to be the most appropriate for the treatment (with a general percentage of removal above $50 \%$ ) and it was easily adapted to the environmental conditions. Therefore, it is possible to consider this sustainable technology using vegetal species to remove As.

\section{ACKNOWLEDGEMENTS}

University of Buenos Aires, Consejo Nacional de Investigación Científica y Tecnológica and Agua y Saneamientos Argentinos S.A.

\section{REFERENCES}

Ciarkowska, K., Hanus-Fajerska, E. \& Gambu, F. 2017. Phytostabilization of $\mathrm{Zn}-\mathrm{Pb}$ ore flotation tailings with Dianthus carthusianorum and Biscutella laevigata after amending with mineral fertilizers or sewage sludge. $J$. Environ. Manag. 189: 75-83. 
Kadlec, R.H. \& Wallace, S.D. 2009. Treatments Wetlands. 2nd ed., CRC Press.

Lizama, K., Fletcher, T.D. \& Sun, G. 2011. Removal processes for arsenic in constructed wetlands. Chemosphere 84(8): 1032-1043.

Valles-Aragon, M.C., Olmos-Marquez, M.A., Llorens, E. \& Alarcón-Herrera, M.T. 2013. Redox potential and $\mathrm{pH}$ behavior effect on arsenic removal from water in a constructed wetland mesocosm. Environ. Prog. Sustain. Energy 33(4): 1332-1339.

Yadav, A.K., Abbassi, R., Kumar, N., Satya, S., Sreekrishnan, T.R. \& Mishra, B.K. 2012. The removal of heavy metals in wetland microcosms: effects of bed depth, plant species, and metal mobility. Chem. Eng. J. 211-212: 501-507. 